\title{
Branding Desa Wisata Berbasis Ecotourism
}

\author{
Prayudi dan Heti Herastuti \\ Proram Studi Ilmu Komunikasi UPN Veteran Yogyakarta \\ Program Studi Agroteknologi UPN Veteran Yogyakarta \\ Email: prayudi73@gmail.com \\ Email: heti_astuti@yahoo.co.id
}

\begin{abstract}
Organic farming is a hallmark of the Kadisobo II Tourism Village urgently to do. Agricultural tourism is a tourism activity that involves the use of agricultural land or related facilities that are an attraction for tourists. If the uniqueness of the tourism village has been formed, then it is necessary to create a coherent perception of the tourism village in the minds of various stakeholders. This is a challenge faced by many organizations. In the context of this study, the effort to make Trimulyo Kadisobo II, Sleman District, Sleman Regency as an ecotourism destination is always in the minds of both internal (community) and external (government, tourists and business) stakeholders is a challenge. Branding can be said as an image of a tourist village that is needed so that the appearance of the tourist village is fresher, more attractive, more remembered by people and in the end people will come to visit the village tour. Furthermore, Sleman Regency as an ecotourism destination will always be in the top of mind of the community as a place that is always interesting to visit. This will be achieved if we can build awareness and curiosity of the community towards tourism villages and ecotourism.
\end{abstract}

Keywords: ecotourism, branding, stakeholder engagement

\begin{abstract}
Abstrak
Pertanian organik menjadi ciri khas Desa Wisata Kadisobo II mendesak untuk dilakukan. Wisata pertanian adalah aktivitas wisata yang melibatkan penggunaan lahan pertanian atau fasilitas terkait yang menjadi daya tarik bagi wisatawan. Jika keunikan desa wisata sudah terbentuk, selanjutnya perlu menciptakan persepsi yang koheren tentang desa wisata di benak beragam pemangku kepentingan. Hal ini merupakan tantangan yang dihadapi oleh banyak organisasi. Dalam konteks penelitian ini, upaya untuk menjadikan Kadisobo II Trimulyo, Kecamatan Sleman, Kabupaten Sleman sebagai daerah tujuan ecotourism selalu berada di benak pemangku kepentingan baik internal (masyarakatnya) maupun eksternal (pemerintah, wisatawan dan pelaku usaha) merupakan sebuah tantangan tersendiri. Branding dapat dikatakan sebagai pencitraan dari desa wisata yang diperlukan agar tampilan desa wisata tersebut lebih segar, lebih atraktif, lebih diingat orang dan pada akhirnya orang akan ramai datang berkunjung ke desa wisata tersebut. Lebih jauh, Kabupaten Sleman sebagai daerah tujuan ecotourism akan selalu berada dalam top of mind masyarakat sebagai tempat yang selalu menarik untuk dikunjungi. Hal ini akan tercapai jika kita bisa membangun kesadaran dan keingintahuan masyarakat terhadap desa wisata dan ecotourism.
\end{abstract}

Kata kunci : ecotourism, branding, stakeholder engagement 


\section{Pendahuluan}

Kabupaten Sleman memiliki potensi di bidang pariwisata yang cukup besar dengan didukung adanya Gunung Merapi yang berjarak $27 \mathrm{~km}$ dari pusat kota Yogyakarta. Wilayah Sleman yang terdiri dari 86 desa memiliki hamparan persawahan yang tampak asri beserta kejernihan air sungai dan udara yang bersih. Suasana khas pedesaan menjadi daya tarik untuk bisa dijual ke wisatawan, sehingga dapat menambah kesejahteraan masyarakat sekitar.

Desa wisata yang ada di wilayah Sleman memiliki potensi untuk dikembangkan menjadi pariwisata yang berkelanjutan atau ecotourism. Ecotourism adalah perjalanan yang bertanggung jawab ke daerah alami yang menjaga lingkungan, mempertahankan kesejahteraan masyarakat lokal dan melibatkan interpretasi dan edukasi khususnya pada staf dan tamu atau wisatawan. Keberadaan desa wisata di wilayah Sleman yang tidak dapat berkembang baik dikarenakan lemahnya kelembagaan desa wisata karena sumberdaya manusia yang tidak kompeten di bidang manajemen maupun pemasaran pariwisata, potensi alam belum dikelola dengan baik padahal dapat meningkatkan penghasilan dan kesejahteraan masyarakat.

Pendampingan pengembangan desa wisata di Kabupaten Sleman telah dilaksanakan selama tiga tahun melalui program Ipteks bagi Wilayah Kabupaten Sleman. Kegiatan yang telah dilakukan adalah pemberdayaan masyarakat meliputi, pelatihan penataan kelembagaan, pelatihan pemandu wisata lokal, penataan paket wisata, penataan lingkungan, pembuatan pupuk organik dan kuliner. Namun karena terkendala kemampuan sdm yang rendah maka tidak percaya diri untuk mempromosikan desanya. Selain itu, potensi yang belum seluruhnya terkelola dengan baik akan menjadi kendala dalam promosi. Dari program IBW yang telah dijalankan di Kadisobo 2, Sleman ini dirasakan masyarakat sangat bermanfaat, dari yang dulunya desa wisata masih embrio menjadi desa wisata berkembang. Namun karena tantangan yang dihadapi sektor pariwisata semakin kompleks dan berat di dalam era pasar yang semakin tanpa batas dan menuntut kemampuan kompetitif, maka diperlukan keberlanjutan program melalui riset.

Berdasarkan penelitian tahun pertama, permasalahan yang teridentifikasi telah diatasi dengan melakukan rekayasa sosial dan pelatihan pertanian organik. Pendekatan stakeholder engagement memungkinkan peneliti mengidentifikasi pemangku kepentingan relevan yang bermanfaat baik pada tahapan pengembangan desa ekowisata, maupun saat pengembangan wisata pertanian dan branding dilakukan pada tahun ke-2 penelitian ini. Berdasarkan penelitian tahun pertama, maka yang akan diteliti lebih lanjut adalah bagaimana desa wisata yang berbasis ecotourism selanjutnya bisa dikuatkan untuk wisata pertanian organik sebagai keunikan desa Kadisobo. Untuk selanjutnya dilakukan proses branding. Semua stakeholder yang bersinggungan dengan ecotourism perlu memiliki pemahaman yang utuh mengenai daerah yang dikunjungi. Pengunjung misalnya, mereka tidak sekedar hanya melihat-lihat, tapi juga memiliki pengetahuan tentang daerah yang dikunjungi, baik kondisi alam, masyarakat lokal, maupun budidaya yang dihasilkan. Oleh karena itu, meneruskan keberhasilan penelitian tahun ke-1, pada tahun ke-2 penguatan wisata pertanian organic menjadi ciri khas Desa Kadisobo mendesak untuk dilakukan. Wisata pertanian adalah aktivitas wisata yang melibatkan penggunaan lahan pertanian atau fasilitas terkait (misal silo dan kandang) yang menjadi daya tarik bagi wisatawan.

Sebuah desa bisa dikatakan menawarkan wisata pertanian karena tawaran yang disajikan di desa itu ialah pemandangan aktivitas warga desa ketika membajak sawah, proses menanam bibit padi dan kegiatan sehari-hari warga Kebonagung. Melalui wisata pertanian ini akan dikenal istilah-istilah baru seperti ngluku, garu, dan tandur. Ngluku dalam Bahasa Indonesia artinya membajak sawah. Aktivitas ini menarik bagi wisatawan karena kegiatan untuk menyuburkan tanah ini masih dilakukan secara manual dengan cara mencangkul, atau menggaruk tanah dengan 
mata bajak yang ditarik sapi atau kerbau. Wisata pertanian yang menjaga keasrian lingkungan dan nilai-nilai lokal masyarakat secara berkelanjutan bisa dikategorikan ekowisata. Jika keunikan desa wisata sudah terbentuk, selanjutnya perlu menciptakan persepsi yang koheren tentang desa wisata di benak beragam pemangku kepentingan. Hal ini merupakan tantangan yang dihadapi oleh banyak organisasi. Dalam konteks penelitian ini, upaya untuk menjadikan Kadisobo II Trimulyo, Kecamatan Sleman, Kabupaten Sleman sebagai daerah tujuan ecotourism selalu berada di benak pemangku kepentingan baik internal (masyarakatnya) maupun eksternal (pemerintah, wisatawan dan pelaku usaha) merupakan sebuah tantangan tersendiri. Branding bisa dikatakan sebagai pencitraan dari desa wisata yang diperlukan agar tampilan desa wisata tersebut lebih segar, lebih atraktif, lebih diingat orang dan pada akhirnya orang akan ramai datang berkunjung ke desa wisata tersebut. Lebih jauh, Kabupaten Sleman sebagai daerah tujuan ecotourism akan selalu berada dalam top of mind masyarakat sebagai tempat yang selalu menarik untuk dikunjungi. Hal ini akan tercapai jika kita bisa membangun kesadaran dan keingintahuan masyarakat terhadap desa wisata dan ecotourism. Untuk mencapai hal ini, perlu dilakukan sebuah pendekatan strategi branding yang sinergitas antara faktor internal dan eksternal. Berdasarkan kondisi empiris di atas, maka rumusan masalah dalam penelitian ini adalah, bagaimanakah pengembangan ecotourism desa wisata dengan pendekatan stakeholder engagement di Kabupaten Sleman. Tujuan Penelitian adalah mengembangkan wisata pertanian organik sebagai keunikan desa wisata, mendesain komunikasi pemasaran dan branding bagi desa wisata, sehingga diperoleh pengembangan desa wisata yang berkelanjutan sesuai dengan prinsip ecotourism. Pada tanggal 1 Januari 2015, The International Ecotourism Society (TIES) telah merevisi definisi dan prinsip-prinsip ecotourism agar lebih bermanfaat bagi banyak orang. Tujuannya adalah untuk memberikan kejelasan, menghilangkan ambiguitas, dan oleh karenanya mengantisipasi misinterpretasi dalam dunia pariwisata. Definisi paling baru dari ecotourism menurutTIESadalahperjalananyangbertanggung jawab ke daerah alami yang menjaga lingkungan, mempertahankan kesejahteraan masyarakat lokal dan melibatkan interpretasi dan edukasi khususnya pada staf dan tamu (responsible travel to natural areas that conserves the environment, sustains the well-being of the local people and involves interpretation and education) (http:// www.ecotourism.org/what-is-ecotourism).

Kebaruan (state of the art) definisi ini adalah dengan dimasukkannya aspek interpretasi dan edukasi dalam definisi ini. Hal ini menjadi penting agar semua stakeholder yang bersinggungan dengan ecotourism memiliki pemahaman yang utuh mengenai daerah yang dikunjungi. Pengunjung misalnya, mereka tidak sekedar hanya melihat-lihat, tapi juga memiliki pengetahuan tentang daerah yang dikunjungi, baik kondisi alam, masyarakat lokal, maupun budi daya yang dihasilkan. Secara konseptul ecotourism dapat didefinisikan sebagai suatu konsep pengembangan pariwisata berkelanjutan yang bertujuan untuk mendukung upaya-upaya pelestarian lingkungan (alam dan budaya) dan meningkatkan partisipasi masyarakat dalam pengelolaan, sehingga memberikan manfaat ekonomi kepada masyarakat setempat. Sementara ditinjau dari segi pengelolaanya, ecotourism dapat didefinisikan sebagai penyelenggaraan kegiatan wisata yang bertanggung jawab di tempat-tempat alami dan atau daerahdaerah yang dibuat berdasarkan kaidah alam dan secara ekonomi berkelanjutan yang mendukung upaya-upaya pelestarian lingkungan (alam dan budaya) dan meningkatnkan kesejahtraan masyarakat setempat. Ecotourism merupakan bentuk wisata yang dikelola dengan pendekatan konservasi. Apabila ecotourism pengelolaan alam dan 
budaya masyarakat yang menjamin kelestarian dan kesejahteraan, sementara konservasi merupakan upaya menjaga kelangsungan pemanfaatan sumberdaya alam untuk waktu kini dan masa mendatang. Di Indonesia, tujuan ecotourism adalah untuk (1) Mewujudkan penyelenggaraan wisata yang bertanggung jawab, yang mendukung upaya-upaya pelestarian lingkungan alam, peninggalan sejarah dan budaya; (2) Meningkatkan partisipasi masyarakat dan memberikan manfaat ekonomi kepada masyarakat setempat; (3) Menjadi model bagi pengembangan pariwisata lainnya, melalui penerapan kaidah-kaidah ecotourism.

Sementara itu destinasi yang diminati wisatawan ecotourism adalah daerah alami. Kawasan konservasi sebagai obyek daya tarik wisata dapat berupa Taman Nasional, Taman Hutan Raya, Cagar Alam, Suaka Margasatwa, Taman Wisata dan Taman Buru. Tetapi kawasan hutan yang lain seperti hutan lindung dan hutan produksi bila memiliki obyek alam sebagai daya tarik ecotourism dapat dipergunakan pula untuk pengembangan ecotourism. Yang paling baru dan sedang menjadi trend di Daerah Istimewa Yogyakarta adalah mulai berkembangnya desa wisata yang menawarkan ke-asri-an alam dan keramahtamahan penduduk lokal. Di dalam pemanfaatan areal alam untuk ecotourism mempergunakan pendekatan pelestarian dan pemanfaatan. Kedua pendekatan ini dilaksanakan dengan menitikberatkan "pelestarian" dibanding pemanfaatan. Kemudian pendekatan lainnya adalah pendekatan pada keberpihakan kepada masyarakat setempat agar mampu mempertahankan budaya lokal dan sekaligus meningkatkan kesejahteraannya. Ecotourism pada prinsipnya tentang menyatukan konservasi, komunitas dan wisata yang berdaya (conservation, communities, and sustainable travel). Hal ini berarti bahwa mereka yang melaksanakan, berpartisipasi didalamnya, dan memasarkan aktivitas ecotourism harus mengadopsi prinsip-prinsip ecotourism berikut: minimalisasi dampak fisik, social, behavioral dan psikologis; membangun kesadaran dan penghargaan terhadap lingkungan dan kultural; memberikan pengalaman positif baik bagi pengunjungan maupun tuan rumah: memberikan manfaat finansial untuk konservasi; merangsang manfaat finansial bagi masyarakat local dan industri swasta; memberikan pengalaman interpretatif yang bisa dikenang bagi pengunjung yang membantu meningkatkan sensitifitas iklim sosial, lingkungan dan politis tuan rumah; merancang, mengkonstruksi dan mengoperasikan fasilitas yang memiliki dampak rendah; mengenali hak dan kepercayaan spiritual penduduk asli dan bermitra dengan mereka untuk menciptakan pemberdayaan.

Secara sederhana bisa disimpulkan bahwa prinsip-prinsip diatas harus menjadi perhatian dari para stakeholders yang berkepentingan agar ecotourism bisa berkembang pesat di daerah yang menjadi target pengembangan. Menurut Geoffrey Wall, Professor of Geography and Recreation and Leisure Studies University of Waterloo, untuk memberikan pengalaman bagi para turis, maka ecotourism secara ekonomis harus giat, layak lingkungan, dan bisa diterima secara sosio kultural. Jika pengalaman yang positif tidak diberikan, maka turis akan enggan datang_berarti tidak ada pariwisata! Jika ecotourism tidak menggeliat dari sisi ekonomi, maka fasilitas dan pelayanan yang banyak dibutuhkan oleh pelaku ecotourism tidak akan ada dan manfaat ekonomi potensial bagi masyarakat lokal dan industry wisata tidak akan tercapai.

Jika lingkungan dan sarananya tidak terpelihara, maka sumber daya ecotourism akan hancur-jika pariwisata berlanjut, agaknya tidak akan bisa menjadi ecotourism kecuali orang dapat meyakinkan pengunjung datang untuk memperbaiki lingkungan yang terdegradasi. Jika ecotourism tidak dapat diterima secara kultural dan masyakat local tidak mendapatkan manfaat darinya, mereka akan terjebak dan bekerja untuk melemahkannya. Dengan demikian, ekonomi, lingkungan dan budaya saling terlibat (Journal of Ecotourism, 2010). Berdasarkan pemahaman ini, menjadi penting untuk melibatkan semua stakeholder 
yang terhubung dengan ecotourism agar pengembangan daerah potensial wisata bisa merangkul semua pihak yang terlibat. Juga mendatangkan banyak wisatawan di daerah dan saat bersamaan memberikan manfaat finansial bagi masyarakat setempat.

Menciptakan persepsi yang koheren dari sebuah organisasi di benak beragam pemangku kepentingan merupakan tantangan yang dihadapi oleh banyak organisasi. Dalam konteks penelitian ini, upaya untuk menjadikan Kadisobo II Trimulyo, Kecamatan Sleman, Kabupaten Sleman sebagai daerah tujuan ecotourism selalu berada di benak pemangku kepentingan baik internal (masyarakatnya) maupun eksternal (pemerintah, wisatawan dan pelaku usaha) merupakan sebuah tantangan tersendiri.

Tom Duncan mendefinikan brand sebagai "sebuah persepsi yang dihasilkan dari pengalaman, atau informasi tentang, sebuah perusahaan atau produk" (2005:70). Sedangkan menurut Interbrand, salah satu perusahaan konsultan brand terkemuka dunia menyatakan brand adalah "gabungan atribut tangible dan intangible, disimbolisasikan dalam merek dagang (trademark), yang jika dikelola dengan baik, bisa menciptakan pengaruh dan mengenerasi nilai" (Clifton \& Maughan, 2000: vii).

Dalam banyak organisasi branding seringkali ditempatkan sebagai bagian dari fungsi komunikasi. Namun, organisasi hanya bisa sukses berkomunikasi jika prilaku organisasi memungkinkannya dan jika produk, pelayanan, finansial, lingkungan kerja, visi dan kepemimpinan, dan tanggungjawab sosial memungkinkanpesanpositifdikirimkepemangku kepentingan (Einwiller \& Will, 2002: 101). Sebagaimana dikatakan oleh Regis McKenna, "brand yang berhasil tidak lebih dari sebuah hubungan yang spesial" (dalam Duncan 2005: 83). Keberhasilan brand bergantung pada bagaimana mempertahankan kepercayaan publik. Hubungannya dengan penelitian ini, branding bisa dikatakan sebagai pencitraan dari desa wisata yang diperlukan agar tampilan desa wisata tersebut lebih segar, lebih atraktif, lebih diingat orang dan pada akhirnya orang akan ramai datang berkunjung ke desa wisata tersebut. Lebih jauh, Kabupaten Sleman sebagai daerah tujuan ecotourism akan selalu berada dalam top of mind masyarakat sebagai tempat yang selalu menarik untuk dikunjungi. Hal ini akan tercapai jika kita bisa membangun kesadaran dan keingintahuan masyarakat terhadap desa wisata dan ecotourism. Untuk mencapai hal ini, perlu dilakukan sebuah pendekatan strategi branding yang sinergitas antara factor internal dan eksternal.

Dalam mengembangkan pemasaran, strategi pencitraan (branding) dan promosi untuk produk ecotourism sangat penting, melalui: kegiatan promosi dan pemasaran berskala internasional; melakukan survei pasar secara berkala untuk mengetahui dinamika pasar; mengidentifikasi target pasar untuk produk ekowisata yang dikembangkan; menyelenggarakan promosi secara khusus (fam trip, mediatrip);membuka danmenjalinhubungan terbuka dengan pihak swasta dan mendorong adanya kesepakatan antara organisasi masyarakat dengan tour operator (Departemen Kebudayaan dan Pariwisata dan WWF-Indonesia, 2009: 4).

\section{Metode Penelitian}

Metode yang digunakan dalam penelitian ini menggunakan metode desriptif kualitatif. Pendekatan kualitatif adalah suatu proses penelitian dan pemahaman yang berdasarkan pada metodologi yang menyelidiki suatu fenomena sosial dan masalah manusia. Pada pendekatan ini, peneliti membuat suatu gambaran kompleks, meneliti kata-kata, laporan terinci dari pandangan responden, dan melakukan studi pada situasi yang alami (Creswell, 2008:15). Penelitian kualitatif dilakukan pada kondisi yang alamiah dan bersifat penemuan. Dalam penelitian kualitatif, peneliti adalah instrumen kunci. Oleh karena itu, peneliti harus memiliki bekal teori dan wawasan yang luas jadi bisa bertanya, menganalisis, dan mengkonstruksi obyek yang diteliti menjadi lebih jelas.

Tujuan dari penelitian ini adalah untuk membuat deskripsi, gambaran secara sistematis, 
faktual dan akurat mengenai fakta-fakta serta hubungan antar fenomena yang diteliti. Whitney (Nazir Moh 2005), menjelaskan penelitian deskriptif adalah pencarian fakta dengan interpretasi yang tepat dan mempelajari situasi-situasi tertentu termasuk tentang hubungan, kegiatan-kegiatan dan pandangan-pandangan. Dalam mengumpulkan data digunakan teknik wawancara dengan menggunakan questioner dan interview guide.

Penelitian deskriptif yaitu penelitian yang bersifat atau memiliki karateristik. Bahwa, data yang ada dinyatakan dalam keadaan yang sewajarnya atau sebagaimana adanya. Mempergunakan cara yang sistematis, terarah dan dapat dipertanggungjawabkan, sehingga tidak kehilangan sifat ilmiahnya (Nawawi 1996:175). Penelitian ini dilakukan di Kadisobo II Trimulyo, Kecamatan Sleman, Kabupaten Sleman yang terletak $20 \mathrm{~km}$ barat laut kota Yogyakarta dan $7 \mathrm{~km}$ dari kota kabupaten Sleman

Data primer diperoleh langsung dari objek penelitian, selanjutnya data tersebut diolah sesuai dengan masalah yang dibahas. Dalam penelitian ini, data primer diperoleh dari para informan yang meliputi masyarakat, pengurus desa wisata, pemuka masyarakat, dan pemerintah (Bappeda, Dinas Pariwisata, Camat). Data sekunder merupakan data yang diperoleh dengan mengutip dari sumber-sumber lain seperti literature, dokumentasi pengurus desa wisata, arsip pemerintah, dan sumber tertulis lainnya yang berhubungan dengan gambaran umum organisasi dan struktur organisasi. Dalam mengumpulkan data-data yang diperlukan penulis menggunakan beberapa cara, antara lain : Penyebaran kuesioner, wawancara dan observasi. Setelah penelitian dilakukan, dari data yang telah dikumpulkan melalui wawancara, observasi dan studi pustaka, data tersebut akan dianalisis. Model analisis terhadap data yang diperoleh baik secara primer ataupun sekunder, dimana hasilnya akan disajikan dalam bentuk uraian dan tidak memakai kaidah-kaidah statistik. Langkah yang dilakukan penulis kemudian adalah menggabungkan data yang terdapat di lapangan untuk diolah dan disederhanakan, lalun disusun secara sistematis untuk kemudian pada akhirnya dilakukan penarikan kesimpulan. Metode Deskriptif merupakan suatu situasi proses dan gejala-gejala atau objek tertentu yang sedang diamati (Ruslan, 2008: 12).

\section{Hasil Penelitian dan Pembahasan}

Desa wisata yang terdapat di Kabupaten Sleman menjadi salah satu alternatif tujuan wisata yang menarik dan sayang untuk dilewatkan. Di desa wisata tersebut para pengunjung bisa menikmati kesegaran dan kenyamanan yang terpancar dari pemandangan alamnya yang indah. Meski sempat menjadi salah satu daerah terdampak paling luas saat terjadi letusan Gunung Merapi tahun 2010, namun abu yang mengguyur kawasan Sleman juga menjadikan tanah di kawasan Sleman lebih subur. Hal inilah yang kemudian menjadikan kawasan Sleman yang hijau menjadi potensi yang sangat besar untuk dikembangkan menjadi tujuan desa wisata.

Desa Kadisobo II adalah sebuah desa yang terletak di wilayah Kecamatan Sleman, Kabupaten Sleman paling utara. Desa Kadisobo II terletak $20 \mathrm{~km}$ barat laut Kota Yogyakarta dan $7 \mathrm{~km}$ dari kota Kabupaten Sleman atau tepatnya ada di Jalan Turi km 4. Luas wilayah Desa Kadisobo II sekitar 85 hektar. Adapun jumlah penduduk 325 jiwa dan $70 \%$ penduduk bermata pencaharian petani, peternak, dan berkebun.

Wilayah Desa Kadisobo II tergolong unik karena dikelilingi oleh hamparan persawahan dan perkebunan salak yang tampak asri dengan dialiri air jernih dari tiga alur sungai, Kali Bedog, Kali Klegung dan Kali Sempor. Desa Kadisobo II juga merupakan daerah dengan peresapan air yang baik. Karena menjadi daerah peresapan air, maka berbagai jenis tanaman tumbuh subur dan sebagian besar masyarakatnya memanfaatkan kesuburan tanah untuk bertani.

Karena struktur geografisnya yang sangat menarik, maka Desa Kadisobo II bisa dikembangkan menjadi sebuah daerah tujuan wisata. Hal ini yang kemudian menjadikan Kadisobo II sering juga disebut sebagai 
Desa Wisata Pertanian. Berbagai kelompok masyarakat juga terlibat dalam kegiatan pertanian antara lain Kelompok Lohjinawi (memproduksi pupuk organik dan tanaman sayur organik), Kelompok Tani Ikan (KTI), PKK dan lain-lain.

Selain wisata pertanian yang sedang ditumbuhkembangkan, ada beberapa jenis wisata lainnya yang memiliki potensi untuk dikembangkan, diantaranya berupa wisata budaya. Wisata budaya yang bisa dikembangkan dan dikemas dengan lebih baik adalah kesenian Pek Bung. Kesenian Pek Bung adalah kesenian tradisional asli dari masyarakat Jawa dengan alat musik tradisional dengan mulai klenting sebagai bas dan kendang, bambu bumbung sebagai bas/gong, seruling untuk melodi, kentongan, besi berbentuk garputala, dan juga bunyi-bunyian lain untuk perpaduan irama.

Wisata budaya lainnya yang bisa dikembangkan adalah pengembangan wisata membatik. Seiring dengan dikembangkannya batik khas Kabupaten Sleman corak parijoto salak, sebenanrnya warga desa Kadisobo II juga bisa mengembangkan keahlian membatik, khususnya kaum wanitanya. Aspek membatik ini agaknya masih kurang mendapat perhatian sehingga perlu dikembangkan. Potensi wisata lain yang juga bisa dinikmati adalah kebun buah salak yang di dalamnya terdapat berbagai jenis tanaman salak (Mozaik Salak). Desa Kadisobo II menerapkan kombinasi unik perkebunan salak pondoh yang para pengunjung dan penikmatnya bisa masuk ke kebun, meresapi tiap detailnya, memetik buah dan mencicipinya, dan membeli salak untuk dijadikan oleh oleh kerabat di rumah.

Kajian mengenai branding desa Wisata mempergunakan lima indikator yang digunakan untuk mengukur persepsi pengelola desa wisata mengenai brand desa mereka sendiri. Persepsi mereka penting untuk diketahui karena seseorang akan bertindak sesuai dengan persepsi yang terbentuk. Indikator yang digunakan adalah tangible feature, saluran komunikasi atau media komunikasi, segmentasi,keyakinandankepuasan.

Dalam penelitian ini, data kuantitatif yang diperoleh dari hasil survey diperdalam dengan hasil pengumpulan data lainnya yaitu wawancara mendalam dengan narasumber yang relevan dan juga sumber-sumber sekunder lainnya. Pembahasan di bawah ini merupakan gabungan antara pengumpulan data yang bersifat kuantitatif dan kualitatif Desa Kadisobo sudah dirintis menjadi desa wisata sejak delapan tahun lalu. Akan tetapi keberadaannya masih belum menunjukkan perkembangan yang signifikan. Pada penelitian tahun pertama, peneliti mengarahkan perhatian bagaimana internal pengelola desa wisata mengelola desa mereka. Aspek sumber daya manusia menjadi perhatian penting pada saat itu. Hal ini dilandasi oleh pemahaman bahwa untuk bisa dikenal oleh masyarakat luas, aspek internal harus siap terlebih dahulu.

Sebagai sebuah desa wisata, mereka memiliki perspesi yang baik mengenai potensi yang dimiliki. Para responden terkesan sangat yakin bahwa desa mereka memiliki potensi yang baik untuk dikembangkan sebagai desa wisata. Ada $78,6 \%$ responden yang sangat setuju jika desa mereka memiliki potensi sebagai desa wisata. Kelebihan desa Kadisobo sebagai desa wisata dapat dilihat dari aspek alam yang terdiri dari landscape, tetumbuhan dan sungai, aspek manusia yaitu potensinya di bidang pertanian organik beserta keramahtamahannya dan juga budayanya yang berakar dari tradisi lokal.

Dalam penelitian yang diadakan pada tahun pertama, ditemukan kondisi bahwa pengelola desa wisata masih berada pada kondisi tidak percaya diri untuk menampilkan desa mereka sebagai desa wisata, meskipun pencanangan desa ini menjadi desa wisata sudah dilakukan sejak tahun 2007. Hal ini terjadi karena sebagai orang yang tinggal di lokasi tersebut sejak lahir maka mereka tidak menganggap tempat itu istimewa tetapi biasa saja.

Desa Wisata Kadisobo bukanlah satusatunya desa wisata yang ada di Kabupaten Sleman. Justru, kabupaten Sleman cenderung aktif dalam merintis dan memasyarakatkan desa wisata sebagai salah satu wisata menarik 
di wilayah ini.. Pada akhir tahun 2013 telah diadakan klasifikasi desa wisata di kabupaten Sleman. Hasilnya adalah dari 38 Desa Wisata terdapat satu desa wisata yang sudah sangat mandiri, 7 Desa Wisata dengan klasifikasi mandiri, 8 desa wisata dengan klasifikasi berkembang, 15 desa wisata berklasifikasi tumbuh dan 3 desa wisata yang kelembagannya perlu diaktifkan lagi (Laksmidewi, 2015:9).

Memang pemerintah kabupaten berusaha agar terdapat perbedaan signifikan antara satu desa wisata dengan desa wisata yang lain. Hal ini dimaksudkan agar tidak terjadi persaingan yang tidak sehat di antara mereka. Selain itu, juga dimaksudkan agar tiap-tiap desa wisata menonjolkan keunikan yang dimiliki. Pada umumnya,keunikanitulahyangmembuatmenjadi berbeda dan lebih mudah diingat oleh masyarakat.

Desa Kadisobo memang memiliki beberapa kelebihan untuk dikembangkan menjadi desa wisata. Namun perlu juga diingat bahwa lokasi desa ini berdekatan dengan beberapa desa wisata yang memiliki kemiripan seperti Desa Wisata Penting Sari, Desa Wisata Pule Sari dan Desa Wisata Brayut. Karena terletak dalam lokasi yang berdekatan, dan berada di sisi selatan Gunung Merapi, maka desa wisata-desa wisata tersebut memiliki kemiripan kondisi geografis maupun budaya. Bahkan, desa wisata tersebut sudah mendapat kategori baik dan sangat baik dari penilaian yang diadakan secara rutin oleh Dinas pariwisata Kabupaten Sleman.

Ketika peneliti menggali lagi apa yang menjadi kelebihan dari desa ini, ternyata jawabnnya belum menunjuk pada satu jawaban yang sama. Para informan memberikan jawaban yangberbeda-beda.Beberapayangmerekaanggap sebagai kelebihan desa Wisata Kadisobo yaitu alamnya yang indah penuh pepohan, ada sungai yang bisa menjadi destinasi wisata, ada lomba burung berkicau yang rutin diadakan seminggu sekali, akses yang mudah bagi para wisatawan, memiliki pertanian organik dan sebagainya. Jawaban mereka sebenarnya tidak keliru karena semua itu merupakan kelebihan dari desa mereka. Namun, yang menjadi pertanyaan besar adalah apa yang akan benar-benar ditonjolkan dari desa mereka. Tampak bahwa pengelola belum memiliki satu keunggulan atau keunikan yang akan ditampilkan. Padahal, menampilkan semua kelebihan sekaligus justru akan membuat masyarakat tidak mudah untuk mengenal desa wisata ini.

Dalam istilah marketing, hal ini dikenal dengan Unique Selling Proposition atau Unique Selling Point (USP) yaitu kelebihan produk atau perusahaan kita dibandingkan dengan pesaing. Jadi USP adalah keunikan dan keunggulan perusahaan kita dibandingkan pesaing. Unik saja tidak cukup, tapi juga harus unggul atau lebih dibandingkan pesaing. USP diharapkan akan mempermudah orang mengingat sebuah produk dibandingkan pesaing atau produk lain yang sejenis. Namun, USP juga sebuah janji atau sebuah hutang yang harus dipenuhi oleh produk yang mengeluarkan USP tersebut. Di sini terlihat bahwa desa wisata Kadisobo belum memiliki USP. Hal ini perlu untuk dikaji secara mendalam karena, sekali lagi, ada kemiripan desa wisata ini dengan desa wisata lain di sekitarnya

Salah satu tren wisata saat ini adalah pada ecotourism yaitu wisata alam yang memiliki tujuan pelestarian lingkungan dan memberikan kesejahteraan pada masyarakat sekitar. Wisata jenis inilah yang saat ini dikembangkan di desa Kadisobo.Untuk mendukung ecotourism, maka pertanian yang dikembangkan adalah pertanian organik. Saat ini mereka sudah memiliki pupuk organik dan pestisida organik yang digunakan untuk keperluan sendiri maupun dijual luas di masyarakat. Pilihan pada pertanian organik juga mengacu pada tren dunia di mana ada kecenderungan back to nature. Selain itu, keyakinan responden juga didasari pada kenyataan bahwa saat ini liburan semakin menjadi kebutuhan dan bahkan budaya baru bagi masyarakat. Seiring dengan meningkatnya pendapatan masyarakat, perubahan gaya hidup, kemajuan teknologi dan transportasi, mendorong munculnya budaya liburan. Pemerintah pun mendorong gejala ini dengan banyak memberikan hari 
libur cuti bersama yang biasanya diletakkan pada akhir minggu atau long weekend. Masyarakat kota yang jenuh dengan rutinitas pekerjaan dan lingkungan kota yang semrawut dan ritme hidup yang tinggi memalingkan mereka untuk berlibur ke desa. Desa yang masih memiliki lingkungan yang asri, udara bersih dan masyarakat yang hangat menjadi salah satu pilihan untuk berwisata. Hal inilah yang ditangkap oleh desa wisata Kadisobo dengn menyediakan paket wisata lengkap dengan layanan homestay. Wisata ini terbuka bagi perorangan (atau keluarga) maupun grup besar. Biasanya wisatawan dalam grup akan ditawarkan untuk mengadakan outbond karena di desa ini sudah terdapat fasilitas tersebut.

Untuk branding yang kuat, diperlukan sebuah keunikan yang ditonjolkan. Jika sebuah produk memiliki banyak keunggulan, maka diharapkan memilih satu keunggulan yang akan ditampilkan. Hal ini juga berlaku dalam pengembangan desa wisata. Tidak dapat dipungkiri bahwa di Kabupaten Sleman ada banyak desa wisata sejenis yang memiliki potensi yang hampir sama dan memiliki potensi alam yang hampir sama karena samasama berada di lereng barat gunung Merapi.

Dinas Pariwisata Kabupaten Sleman sebenarnya sudah menekankan keharusan adanya ciri pembeda antara satu desa dengan desa yang lain. Namun tampaknya ciri pembeda berupa "Desa Wisata Ekowisata berbasis pertanian organik" belum cukup dihayati oleh pengelola. Jika penghayatan terhadap hal tersebut belum ada, maka bagaimana akan merealisasikan branding. Sementara itu, jika branding yang diterapkan adalah Ekowisata namun kenyataan di lapangan tidak ditemukan oleh wisatawan (underdelivery), maka akan menimbulkan kekecewaan. Peneliti melakukan identifikasi unsur-unsur komunikasi yang menunjang branding desa wisata. Hasil identifikasi tersebut dapat di lihat pada gambar 1 . Model branding di atas menjadi model pertama yang dapat diterapkan oleh pengelola, karena selama ini mereka belum memiliki sebuah perencanaan branding. Pemahaman mengenai branding pun masih amat terbatas. Beberapa hal yang memerlukan pencermatan adalah pada kesamaan visi dan misi pengelola dan antisipasi mereka jika desa wisata ini kelak berkembang dan dikunjungi banyak wisatawan.

Hal lain adalah aspek manajemen di mana mereka perlu bekerja dengan urutan perencanaan, pelaksanaan dan evaluasi. Aspek perencanaan media juga perlu mendapat perhatian lebih dari pengelola. Bagaimana pun juga medialah yang akan menjangkau khalayak untuk menarik perhatian calon wisatawan. Organisasi pengelola juga perlu

Gambar 1. Branding Desa Wisata Berdasar Unsur-unsur Komunikasi

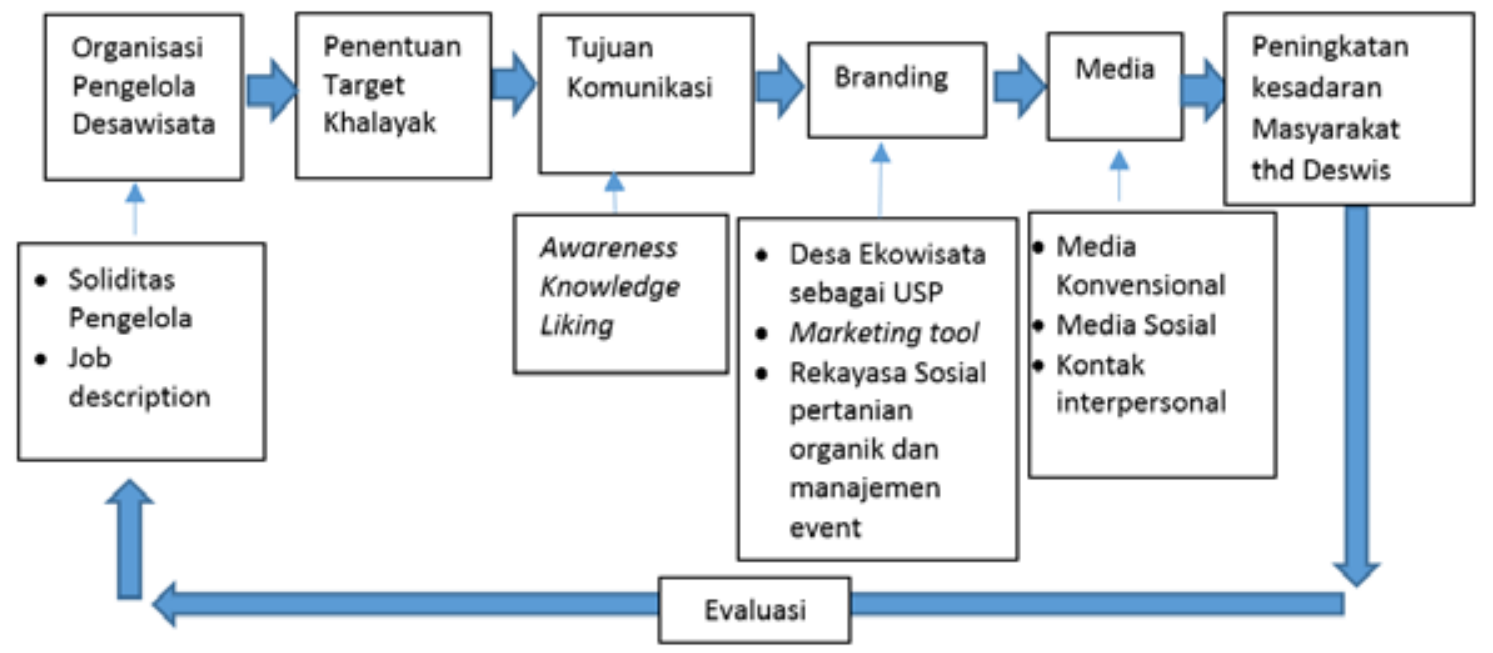


diregenerasi untuk mendapatkan pengelola dengan usia yang lebih muda. Hasil penelitian menunjukkan bahwa komposisi pengelola didominasi mereka yang berusia tua. Mereka yang telah senior dapat menjadi pendamping bagi pengelola yang lebih muda. Pengalaman mereka tentu dapat dimanfaatkan oleh generasi muda.

Dalam hal media, mereka tidak memiliki perencanaan yang sistematis baik jangka panjang maupun jangka pendek. Media komunikasi yang digunakan memang sudah menggunakan media konvensional, media sosial dan kontak interpersonal, akan tetapi kesemuanya itu masih dilaksanakan secara sporadis. Dimuatnya desa wisata ini di media cetak atau elektronik berasal dari inisiatif media sendiri, misalnya meliput sebuah event yang besar. Belum ada media relations yang dijalankan oleh pengelola. Media sosial juga belum dioptimalkan sesuai dengan fasilitas yang ada. Pengelolaan masih seperti akun pribadi yang tidak memiliki target tertentu. Saat ini juga website dalam kondisi suspended karena belum membayar biaya hosting. Hal ini menjadi sebuah kerugian besar untuk menjangkau khalayak yang lebih besar. Pengelola menghadapi persoalan ketiadaan dana untuk berpromosi melalui berbagai media. Mereka juga belum punya marketing tool yang diperlukan dalam sebuah kegiatan branding seperti logo, spot foto, ikon desa dan sebagainya

\section{Simpulan}

Branding ekowisata berbasis pertanian organik sebenarnya cukup unik sebagai USP dan berbeda dengan desa-desa wisata yang lain. Masyarakat desa tidak perlu mengada-adakan lagi untuk membentuk desa mereka sebagai desa ekowisata, yang perlu dilakukan hanya mengubah pemahaman dan kebiasaan bertani menjadi bersifat organik.

Untuk bisa melakukan kegiatan branding yang baik, diperlukan peralatan pemasaran dan media serta konsistensi dalam pelaksanaan. Di desa wisata Kadisobo belum memiliki marketing tool seperti logo, spot selfie, ikon desa dan sebagainya. Kegemaran ber-selfie para pengunjung tidak boleh diabaikan dan jusru perlu diakomodir dengan membuat spot selfie yang ikonik. Marketing tool juga bisa dilakukan melalui hal lain, tergantung kreatifitas pengelola.

Model branding yang ditawarkan didasarkan pada elemen-elemen komunikasi yang berurutan dari Sumber, pesan, media, penerima, efek dan umpan balik. Sekilas ini seperti model generik, tetapi untuk penerapan di desa Kadisobo, masih banyak yang perlu dikembangkan pada setiap elemennya Pada aspek organisasi, misalnya, disparitas usia pengelola tampak cukup tinggi. Hal ini diduga berpengaruh pada kinerja dalam memasarkan desa wisata. Demikian juga belum ada sebuah sistem dan prosedur mengenai yang menjelaskan hal-hal penting mengenai hak dan kewajiban pengelola dalam jangka panjang.

Dari sisi media, belum ada sebuah perencanaan media yang jelas. Bahkan tidak ada pendanaan untuk hal ini. Semua media yang dipakai saat ini masih bersifat sporadis dan belum didasarkan pada sebuah perencananan yang matang. Tetapi, satu hal yang perlu dicatat adalah bahwa desa wisata ini mulai menarik perhatian media lokal dan juga pelaku industri wisata di Yogyakarta. Sebenarnya di era internet, pengelola dimudahkan dengan adanya media sosial. Namun media sosial juga perlu dirawat dan dipelihara agar lebih menarik perhatian dan menjakau khalayak luas. Fasilitas-fasilitas yang ada belum semua dimanfaatkan sehingga masih mirip dengan akun personal yang tidak berkepentingn bisnis. Untuk kepentingan bisnis, media sosial juga perlu diiklankan secara profesional. Konsekuensinya, pendanaan menjadi salah satu hal yang mesti disediakan.

Saran untuk untuk pengelola desa wisata, perlu diadakan evaluasi secara mendasar dari semua elemen komunikasi yang dipaparkan dalam model branding di atas. Evaluasi diperlukan mengingat setelah delapan tahun desa ini mencanangkan diri sebagai desa wisata, perkembangannya belumbegitu signifikan. Aspek kelembagaan perlu ditata ulang dan pada saat 
yang sama mengaktivasi media sosial yang ada serta membuat marketing tool seperti selfi corner.

Saran untuk Dinas Pariwisata kabupaten Sleman agar lebih menekankan diferensiasi masing-masing desa wisata. Desa wisata yang terlalu mirip dengan desa wisata yang lain tidak akan memperkaya destinasi wisata di kabupaten Sleman. Selain itu, model pembinaan desa wisata sebaiknya berkesinambungan dan berupa pendampingan. Penguatan kapasitas organisasi pengelola perlu dilakukan. Masyarakat amat membutuhkan pendampingan karena mengelola desa wisata yang memiliki konsekuensi ekonomi ternyata merupakan hal yang baru bagi mereka. Desa wisata mutlak perlu dikelola secara profesional dan jauh dari kesan amatir. Diharapkan hal ini akan berimbas pada pelayanan dan kepuasan wisatawan yang berkunjung Untuk penelitian yang akan datang, sebaiknya dilakukan dalam kurun waktu yang panjang (longitudinal research) untuk melihat perubahan-perubahan dari waktu ke waktu. Jika model branding yang diusulkan dalam penelitian ini diterapkan, peneliti perlu mengadakan penelitian sejauh mana branding ini bekerja. Jadi, apabila pemerintah perlu mengadakan pendampingan, maka peneliti pun lebih baik melihat perkembangan yang terjadi secara berkesimbungan.

\section{Daftar Pustaka}

Clifton, R. dan Esther M(Ed.) (2000). The Future of Brands: Twenty-five Visions. New York: New York University Press \& Interbrand.

Creswell, J. W. (1998). Qualitative Inquiry and Research Design. New York: Sage Publications. Departemen Kebudayaan dan Pariwisata dan WWF-Indonesia. (2009). Prinsip dan KriteriaEkowisata Berbasis Masyarakat. Duncan, T. (2005). Principles of Advertising and $I M C$ (edisi kedua). New York: Mc Graw-

Hill.

Einwiller, S. \& M. Will. Towards an

$\begin{array}{lrr}\text { Integrated Approach to } & \text { Corporate } \\ \text { Branding-an } & \text { Empirical Study. }\end{array}$

$\begin{array}{lrr}\text { Integrated Approach to } & \text { Corporate } \\ \text { Branding-an } & \text { Empirical Study. }\end{array}$
Corporate Communication: An

International Journal. Volume 7, Nomor 2. (2002). Hal. 100-109. Herastuti, H. et al. (2014). LaporanAkhir Program Ipteks bagi Wilayah (IbW). LPPM UPN Veteran Yogyakarta \& LP2M Sekolah Tinggi Pariwisata AMPTA Yogyakarta.

Kahootz. Transforming Public Sector Stakeholder engagement. Berkshire. Moleong, L. J. (2006). Metode Penelitian Kualitatif (Edisi Revisi). Bandung: Remaja Rosdakarya Rakhmat, J. (1998). Metode Penelitian Komunikasi. Bandung: Rosda Karya. Ruslan, R. (2008). Metode Penelitian Public Relations dan Komunikasi. Rajawali Press.

Sutopo, H.B. (2002). Metodologi Penelitian Kualitatif. Surakarta: UNS Press. Torfaen County Borough Council. (2006). Stakeholder engagement-A Toolkit. REVIT

Project.

The International Ecotourism Society (TIES). (2015). What is Ecotourism. Alamat Web: http://www.ecotourism.org/what-is-ecotourism Wall, G. Ecotourism: Change, Impacts, and Opportunities. Journal of Ecotourism. (2010). 